\title{
Experimental Investigations on the Genus Drimys.
}

\author{
BY
}

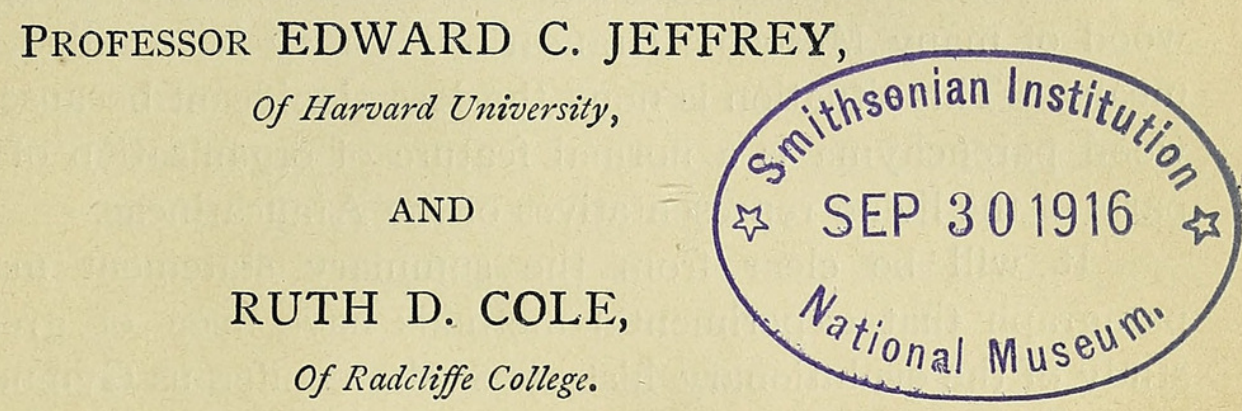

With Plate VII.

F XPERIMENTAL investigation has come prominently into the foreC ground in many lines of botanical work in recent years. In no case, perhaps, is its value so clear as in the case of the Conifers, which present the great advantage of a long anatomical history displayed in the strata, by means of which experimental results may be controlled. An interesting general result which has been derived from united palaeobotanical and experimental study in the case of the Conifers is that the more simply organized subtribes of the group are derived from ancestors with more complex anatomical structures. One of us pointed out a number of years ago, ${ }^{1,2}$ that in the genus Sequoia and in those genera of the Abietineae without normal resin canals in the secondary wood (Abies, Tsuga, Psendolarix, and Cedrus), resin canals reappear as a consequence of injury. This reappearance of secretory canals as a phenomenon of injury is particularly significant because these structures are found to a large degree normally in the more conservative regions of the genera named. Later investigations have shown further that the rays of certain Conifers may be modified experimentally in an interesting way. First, in the genus Cunninghamia ${ }^{3}$ it was demonstrated that a frequent result of injuries was the appearance of marginal ray tracheides, such as are characteristic of the pine-like

1 Jeffrey, E. C.: The Comparative Anatomy of the Coniferales. I. The genus Sequoia. Mem. Boston Soc. Hist., vol. v, I903, pp. 44I-59, Pls. 68-7I.

2 Jeffrey, E. C.: The Comparative Anatomy of the Coniferales. II. The Abietineae. Mem. Boston Soc. Nat. Hist., vol. vi, I904, pp. I-37, Pls. I-7.

3 Jeffrey, E. C.: Traumatic Ray Tracheides in Cunninghamia sinensis. Ann. Bot., vol. xxii, 1908, pp. 593-602, P1. XXXI.

[Annals of Botany, Vol. XXX. No. CXIX. July, rg16.]

C C 
Abietineae but are not normally present in the rays of this genus. Later, Miss Holden ${ }^{1}$ made clear that the possibility of the recall of marginal tracheides was widespread in both the Taxodineae and Cupressineae. Professor W. P. Thompson ${ }^{2}$ has demonstrated a similar situation in the genus Abies among the higher Abietineae, where, as a consequence of injury and especially in the root, ray tracheides make their appearance. Recently ${ }^{3}$ it has been shown that in the existing araucarian Conifers the parenchymatous elements found as a normal feature of organization of the wood of many Mesozoic Araucarioxyla may be recalled by experimental means. This situation is none the less significant because the presence of wood parenchyma is a normal feature of organization of the conservative parts of the living representatives of the Araucarineae.

It will be clear from the summary statement made in the last paragraph that experimental methods have been of great value in the study of the evolutionary history of the coniferous Gymnosperms. In the case of the Angiosperms the fossil record is at the present time extremely incomplete so far as structural remains are concerned; and the study of existing forms by experimental procedure is as a consequence of even greater importance relatively than it is in the Conifers. In the present communication it is proposed to show the value of the study of abnormal material in the case of the non-vascular magnoliaceous genus Drimys. The absence of vessels in this interesting genus of the Southern Hemisphere was noticed in the early forties of the last century by Goeppert (Goeppert, Linnaea, I6. I842). This condition is of particular interest in view of the speculations in regard to the origin of the Angiosperms, which in the case of certain investigators have been made to centre around the Magnoliaceae. The floral organization of the Magnoliaceae and related families has been the main point of argument in this connexion. Obviously it is well to consider possible evidence of the primitive character of the group from anatomical characteristics. Clearly the absence of vessels, if an original condition in the Magnoliaceae, would furnish a strong indication in this direction, were the gymnospermous forms hypothetically antecedent to the Angiosperms themselves non-vascular. If the Gnetales are ancestral to the Dicotyledons, as has been suggested by Arber and Parkin ${ }^{4}$ as well as other investigators, evidently the absence of vessels in any angiospermous

\footnotetext{
1 Holden, Ruth: Ray Tracheides in the Coniferales. Bot. Gaz., vol. 1v, No. I, Jan. I9I3, Pls. I and II.

${ }_{2}$ Thompson, W. P.: Ray Tracheides in Abies. Bot. Gaz., vol. liii, 19I2, pp. 33 I-8, Pls. XXIV, XXV.

${ }^{3}$ Jeffrey, E. C.: The History, Comparative Anatomy, and Evolution of the Araucarioxylon Type. Part I. Proceedings of the American Academy of Arts and Sciences. Vol. xlviii, No. I3, Nov. 1912.

4 Arber, E. A. Newell, and Parkin, John : On the Origin of Angiosperms. Journ. Linn. Soc., London, Bot., vol, xxxviii, 1907, pp. 29-80.
} 
group cannot with any degree of probability be regarded as a primitive feature.

The material used in the present investigation was collected at the request of the senior author by travelling Fellows of Harvard University in New Zealand and in Java, and care was taken to secure seedlings as well as parts of mature plants. Wounded conditions were particularly sought for on account of the proved value of wound reactions in the case of both Conifers and Dicotyledons. Abundant material of Drimys colorata and a moderate amount of $D$. axillaris were available from this source. We are indebted to the Director of the Royal Gardens, Kew, England, for small twigs of $D$. Winteri and $D$. aromatica. Through his kindness we have likewise been enabled to study the organization of the interesting genera Trochodendron and Tetracentron, which are also devoid of typical vessels.

The wood of Drimys, apart from the absence of vessels, strongly resembles in general appearance that of one of our northern oaks, for it is characterized by conspicuously large rays in striking contrast to others a single row of cells in breadth. Fig. I, Pl. VII, shows the general organization of the wood of $D$. colorata as seen in transverse section. To the right and left are indications of the broad rays of the oak type. The mass of wood in the centre is radially traversed by narrow and uniseriate rays. The annual rings are somewhat indistinct, a result of the mild climatic conditions under which the plant has flourished. They are most clearly marked by a terminal zone of parenchyma. Fig. 2, Pl. VII, reproduces the tangential aspect of the wood in $D$. colorata under a moderate degree of magnification. Laterally are the large rays as in the preceding figure, and in the centre lies the mass of wood penetrated by the linear or uniseriate rays. Wood parenchyma is not seen in the field of view. Fig. 3, Pl. VII, shows a part of the wood of $D$. colorata, somewhat highly magnified. The narrow rays alone are evident, and the fact that they are uniseriate is now quite apparent. The mass of the wood is composed of tracheides which are thick-walled and angular in shape. Wood parenchyma appears tangentially as thin-walled elements which look black in the photograph.

The characters of the longitudinal elements or tracheides are of greatest interest in the present connexion. Fig. 4, Pl. VII, represents a rather high magnification of a radial view of the wood in D. colorata. To the right may be seen parenchymatous cells, the remainder of the field showing only tracheary elements. The pits in the latter are in a single row and do not usually become flattened by mutual contact, thus scarcely justifying the comparison with the wood of the araucarian Conifers which has often been made. Fig. 5, Pl. VII, supplies a view of the wood of D. axillaris under a similar magnification. Parenchymatous elements are 
in this case likewise present on the right, while the illustration as a whole shows only parts of tracheides. The pits are appreciably smaller than are those of $D$. colorata in the preceding figure. Fig. 6, Pl. VII, shows a view of the root wood of $D$. colorata. The pits are now in two rows, in contrast to the single series characteristically present in the woody structures of the stem. The increase in number of pits appears to be a usual feature of organization of the wood of the root both in Dicotyledons and Conifers. The pores of the tracheides in the figure alternate in the araucarian manner, but are not deformed by approximation and mutual pressure as in the subtribe of Conifers indicated.

The most interesting conditions which have been observed in the present connexion have been found in the case of the root wood, when injured. Two large adult roots and the roots of a number of seedlings of $D$. colorata showed the presence of healed wounds. For comparison with these was available a large amount of normal material. It should be stated that the results recorded here depend on the examination of a considerable number of preparations, and have to that extent a general validity. Fig. 7 , Pl. VII, reproduces part of a longitudinal radial section of a wounded root in the vicinity of the injury. To the left in the figure appear tracheides filled with a dark gummy material, which is one of the consequences of injury. A curious phenomenon is seen in some of the tracheides, most strikingly visible in the fourth element from the right. Here, instead of the rows of separate rounded pits, which are characteristic of the normal structure of the root, we find elongated scalariform pits, such as are often present in vessels of the Magnoliaceae and other dicotyledonous families. To the left of the element under discussion is one in which the scalariform pitting is less pronounced, and in the next tracheide to the right of the first described it can scarcely be observed. Fig. 8, Pl. VII, shows another field of view from a different root (likewise wounded). Crowded pitting occurs in the tracheides on the right and left of the figure. To the left of the centre in the figure lies a tracheide in which scalariform pitting is a marked feature. A careful inspection of the pits in the upper and lower regions of this element makes it clear that the scalariform pits are the result of the fusion of the rounded pores, which are a feature of the organization of the normal tracheides of the wood of the root. Two or three rows of parenchyma can be made out in the illustration. Fig. 9, Pl. VII, furnishes us with still another view of injured wood in the root of $D$. colorata. Here may be observed a great variety of conditions in regard to the fusion of pits in the tracheides. In an element to the left of the centre the condition of fusion is very marked, and the scalariform pores resulting from it are as a consequence much elongated. Farther to the right and left all stages of fusion may be made out in the case of the small round pits, which are a normal type of pore in the elements of the root. An examination of 
a considerable amount of material makes it clear to us that, so far as the root of $D$. colorata is concerned, the appearance of scalariform pitting is the usual result of injury in a smaller or larger number of the tracheides. Similar phenomena were found to hold for seedlings as well as the root of the adult.

It is natural to compare the conditions resulting from injury in the stem of $D$. colorata with those found in the root. A much more limited amount of material was at our disposal in the case of this organ. A large number of sections have been prepared, however, both of the adult and seedling wounded stem. In no instance was there any indication of the fusions of pits such as are found quite generally in the lateral walls of the vessels of the vascular Magnoliaceae, as well as other dicotyledonous families ordinarily regarded as holding a higher systematic position. It seems natural to explain the difference of behaviour of these two organs in the case of injuries, so far as they may not be due to the limited amount of material of the injured stem, to the greater conservatism of the root. The significance of this statement will become apparent at a later stage.

As a preliminary to the interpretation of the results of injury in the case of Drimys, it is necessary to devote some attention to the general features of organization of the vessel in the Magnoliaceae (including the Trochodendraceae) as a whole. The monotypic genus Liriodendron will serve to point the present remarks, although it is well to state that a large number of other genera have likewise been examined in the present connexion. Fig. IO, Pl. VII, shows the organization of one of the vessels in the root of Liriodendron tulipifera. The vessel is flanked on either side by other elements of the wood, both fibrous and parenchymatous. The trachea or vessel is of most importance from the standpoint of the interpretation of the traumatic phenomena of Drimys. In the upper and lower regions of the wall may be seen rows of opposite pits, which are clearly bordered and serve to bring about lateral relations with an adjoining vessel. Starting from the middle of the vascular element and descending may be seen a region of actual perforation, affording an unimpeded communication with another below the plane of section. The apertures in this case are the result of the loss of borders and likewise the partial fusion of the pits, which characterize the lateral walls of the vessel. The correctness of this interpretation may be easily inferred from an inspection of the figure. For comparison with Fig. IO, Pl. VII, another vessel from Liriodendron of somewhat different type is presented in Fig. II, Pl. VII. Here the lateral pits are for the most part elongated and belong to the type known as scalariform. In the region below the middle the vessel is perforated in this instance, as in the other case, so that the openings have resulted from the lateral pits having lost their membranes as well as their borders. 
The fusion of pits observed in the foregoing figure is not here apparent, since it has already taken place in the lateral walls.

It is clear from the observations recorded in the preceding paragraph that the vessels of Liriodendron are distinguished from the tracheides by their larger calibre, the numerous pits of the lateral walls, either opposite or fused to constitute scalariform pores, and finally by the scalariform perforations, bringing about open communication between vessel and vessel. These perforations are obviously the result of modification of the opposite rows of lateral pits or of the scalariform fusions of these. It thus becomes evident that the vessel in types like Liriodendron is not far removed from the tracheide in its organization, although it possesses the distinctive features of a vessel. In some instances the perforations may be absent, but the essentially vascular character of the element may then be inferred from the numerous opposite or fused (scalariform) pits of its lateral walls, as well as from its characteristically large calibre. There is an interesting resemblance between the vessels of Liriodendron, in fact, and those found in certain Ferns and other Vascular Cryptogams. In Pteris aquilina, for example, vessels take their origin from the disappearance of the borders and membranes of certain of the scalariform pits of the wall. It is important to note, however, that in Pteris and similar forms the scalariform pitting is a primitive feature of organization, while in the Dicotyledons it has been derived secondarily by the fusion of opposite rows of pits in the lateral walls of the vascular elements.

The considerations put forward in the two preceding paragraphs bring us to the discussion of the scalariform elements found in proximity to the protoxylem in Drimys and in an indefinitely wider region in Trochodendron and Tetracentron. Those scalariform elements lying farther away from the primary region of the wood are of significance in the genus Drimys. Here one finds a marked tendency to scalariform pitting in the terminal regions of the tracheary elements, after it has been superseded in the rest of the walls by typical round bordered pits. In the case of Drimys we are left in doubt by reason of the proximity of the elements to the scalariform tracheides of the primary wood. In Trochodendron and Tetracentron, however, this ambiguity does not occur, since the vessel-like tracheides are found in regions far outside the primary wood and consequently cannot reasonably be interpreted as persistent scalariform elements of the firstformed wood.

The conditions resulting from wounding in the case of Drimys, nevertheless, seem to throw more light on the subject under discussion than is afforded by the study of the first annual ring, the leaf, and the root, all regions which we have been led as a consequence of the investigations on gymnospermous anatomy in recent years to regard as the seats of ancestral characters. By reason of the possibility of the confusion of 
degenerate vessels with the similarly organized scalariform elements of the primary wood the question of interpretation becomes difficult. The situation, therefore, may be compared somewhat accurately with that in Sequoia sempervirens. In this species resin canals are formed as a result of injury, and do not, as in the allied species $S$. gigantea, occur in the primitive regions-first annual ring, leaf trace, and cone axis and its scales. Traumatism in the redwood ( $S$. sempervirens) supplies, in fact, the only evidence as to its former possession of resin canals, while in the big tree (S.gigantea) traumatic evidence is reinforced by the conditions found in the conservative organs. The situation in Drimys may also be compared quite accurately with the wood phenomena presented by the rays of the Taxodineae and Cupressineae in general as described by Miss Holden ${ }^{1}$ and one of us. ${ }^{2}$ Here the return of ray tracheides has been observed only as the result of injury, and is not found normally in any of the regions recognized as conservative.

But if it be granted that the vessel-like structures which occur traumatically in the injured root are distinct evidence of the former presence of vessels in Drimys, we have still certain difficulties to consider. First, there arises the question whether the structures under discussion are in reality to be regarded as degenerate vessels in reversionary return. Secondly, there is the equally important problem as to whether it is inherently probable that any group or genus of Angiosperms can primitively have possessed vessels and have subsequently lost them.

Taking the question of interpretation first, we may ask if the peculiar scalariform elements occurring in the root of Drimys after injury are in reality to be interpreted as of the nature of vessels. They are certainly not to be considered as tracheides, since the sculpture of their walls is quite unlike that found in tracheides in general, and entirely resembles that observed as characteristic of vessels in the Magnoliaceae and other families. The only difference between the structures in question and typical vessels is the absence of actual perforations. This, however, is not a serious objection. In the Cactaceae and Crassulaceae among the Dicotyledons are found vessels which by the loss of their terminal pores have ceased to be technically of the character of vessels. An examination of the genus Opuntia among the Cactaceae by Miss Bliss, working in this laboratory, has made it clear that what are occluded elements of a vessel-like nature in the later wood are patent vessels in the region of the pith. In certain of the Magnoliaceae, where the vessels have not only scalariform perforations but also scalariform pits on their lateral walls, we have merely to imagine

1 Holden, Ruth: Ray Tracheides in the Coniferales. Bot. Gaz., vol. lv, No. I, Jan. I9I3, Pls. I and II.

2 Jeffrey, E. C. : Traumatic Ray Tracheides in Cunninghamia sinensis. Annals of Botany, vol. xxii, r9o8, pp. 593-602, Pl. XXXI. 
the scalariform perforations obliterated by the reduction in calibre and development to realize structures of the same nature as those occurring traumatically in Drimys. This interpretation, moreover, gains force from the fact that in Liriodendron such degenerate vessels are of normal, although rare, occurrence. Further, the general phenomena of traumatism lead us to expect, more often than not, the recall of ancestral characters in an abnormal form. This is, for example, pre-eminently true of the traumatic resin canals and traumatic ray tracheides of the Conifers. A final argument for the interpretation of the curious elements appearing in the root of Drimys as a consequence of injury as reversionary indications of the former presence of vessels in the genus is that such an hypothesis explains the fact satisfactorily. If the opposition and fusion of pits in the tracheides of the root in Drimys were only a meaningless vagary, we should expect to find parallel conditions in the injured woods of Conifers. Such have never been described.

We may now pass to the question of the inherent probability of the suppression of vessels in angiospermous woods. The evidence appears to be overwhelmingly in favour of such a possibility. Fig. I2, P1. VII, illustrates part of the woody cylinder of Almus japonica. In the centre there is a broad radial zone of the wood devoid of vessels, and laterally several similar non-vascular stripes of less diameter may be seen. The broad central band of vessel-less wood corresponds in position to the leaf trace. Such conditions are found in a number of cases in woody Dicotyledons, and are of very wide occurrence among the herbaceous representatives of the group. It has been shown by investigations carried out by students of this laboratory that the evascularization of wood is a phenomenon commonly related to the transformation of regions of the woody cylinder into parenchyma. In the case of Almus figured above, it is quite easy to observe the gradual blotting out of the typical vascular organization as one progresses from the region of the leaf gap outwards. Since there is absolutely no question that vessels may degenerate in the Dicotyledons locally, there seems to be no difficulty in regarding as possible the occurrence of this phenomenon as a general feature of organization, particularly as this situation is actually realized in certain Cactaceae and Crassulaceae, as indicated above. Further, if the Gnetales or similar forms are ancestral to or cognate with the Angiosperms, the possession of vessels is clearly a primitive characteristic of the higher seed plants known as Angiosperms.

In conclusion we may attempt to picture to ourselves the type of wood structure from which Drimys has been derived. As has been pointed out in the beginning, the general organization of the wood, apart from the absence of vessels, is that of one of our northern oaks. There is good reason, both on account of its early abundant occurrence as a fossil and likewise on comparative anatomical grounds, to regard the oak as a relatively primitive 
dicotyledonous type. If the resemblance to oak wood in general organization is of value, it is clear that Drimys has come from a comparatively primitive Ranalian type. Although the general structure of the woody tissues of the genus under discussion is primitive, the absence of vessels cannot apparently, in view of the present investigation, be so regarded. It seems quite clear that the ancestors of Drimys possessed vessels, and that these were of a type characterized by lateral scalariform pits and probably by scalariform perforations. The absence of perforations is merely a technical distinction between tracheides and vessels in the case of the Dicotyledon, and has no d ecisive evolutionary significance. No discussion of the evolutionary history in the case of vascular structures is complete unless the lateral as well as the end walls of the vessels are taken into consideration.

\section{SUMMARY.}

I. The roots in Drimys, in particular D. colorata, as a consequence of injury develop peculiar tracheary structures.

2. The structures in question are regarded as the abortive and reversionary return of vessels because of the resemblance of the sculpture of their lateral walls to that found in the vessels of the Magnoliaceae.

3. These traumatically induced elements are characterized by the opposition and fusion of rows of pits, and in this respect are clearly distinct from ordinary tracheides. They, however, lack the perforations of normal vessels.

4. In spite of the absence of perforations, they are apparently to be interpreted as a clear indication of the former presence of vessels in Drimys and similar forms among the Magnoliaceae.

5. Drimys is a representative of the Magnoliaceae primitive in position, as evidenced by its ray structures and the character of its traumatically recalled vessel-like elements.

\section{DESCRIPTION OF PLATE VII.}

Illustrating Professor Jeffrey and Miss Cole's paper on Drimys.

PLATE VII.

Fig. I. Transverse section of wood of Drimys colorata, showing absence of vessels and broad and uniseriate rays. $\times 40$.

Fig. 2. Longitudinal tangential section of the wood of D. colorata. $\quad \times 5^{0}$.

Fig. 3. Transverse section of wood of $D$. colorata. $\times 125$.

Fig. 4. Longitudinal radial section of wood of stem of $D$. colorata. $\times 125$.

Fig. 5. Longitudinal radial section of wood of stem of D. axillaris. $\times 125$.

Fig. 6. Longitudinal radial section of root wood of D. colorata. $\times 125$. 


\section{Feffrey and Cole.-Investigations on the Genus Drimys.}

Fig. 7. Longitudinal radial section of wood of injured root of $D$. colorata. To the left tracheides occluded with gummy matter resulting from injury. To the right more or less vessel-like tracheary elements. $\times 75$.

Fig. 8. Another longitudinal radial section of injured wood of root of $D$. colorata, showing wood parenchyma, tracheides, and one clearly vessel-like element. $\times 125$.

Fig. 9. Still another longitudinal radial section of the same, showing a variety of vessel-like structures formed as a consequence of injury. $\quad \times 125$.

Fig. Io. Longitudinal radial section of the wood of the root of Liriodendron tulipifera. In the centre is seen a vessel of rudimentary type indicating clearly the origin of perforations from modified pits. $\times 75$.

Fig. II. Radial section of root of L. tulipifera, showing vessel in the centre. The lateral pits of the vessel are scalariform, and the perforations originate from the loss of border and membrane in certain of these. $\times 125$.

Fig. 12. Transverse section of portion of a three-year-old twig of Alnus japonica, showing the disappearance of vessels in the segment of the woody cylinder corresponding to a leaf trace. $\quad \times 20$. 

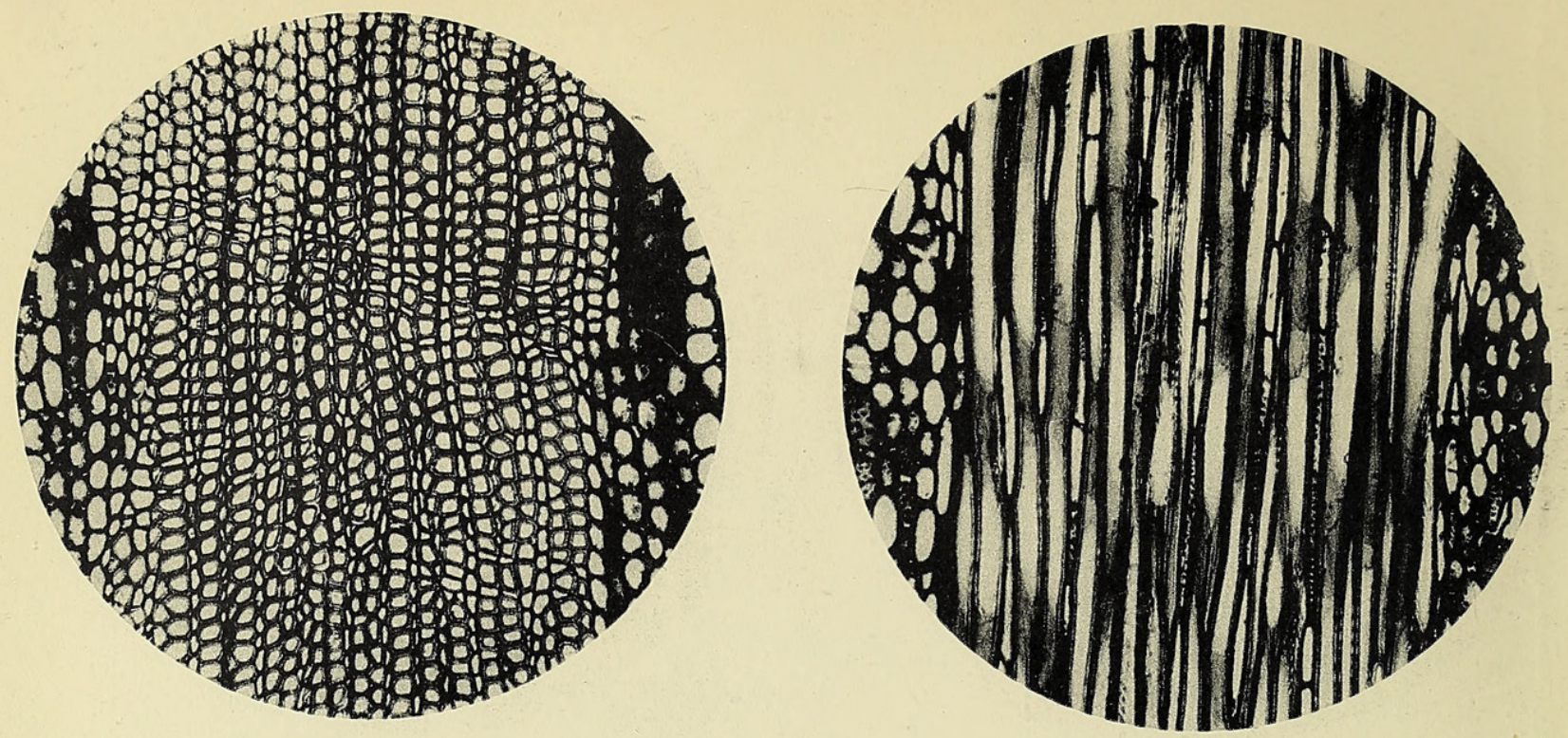

1.
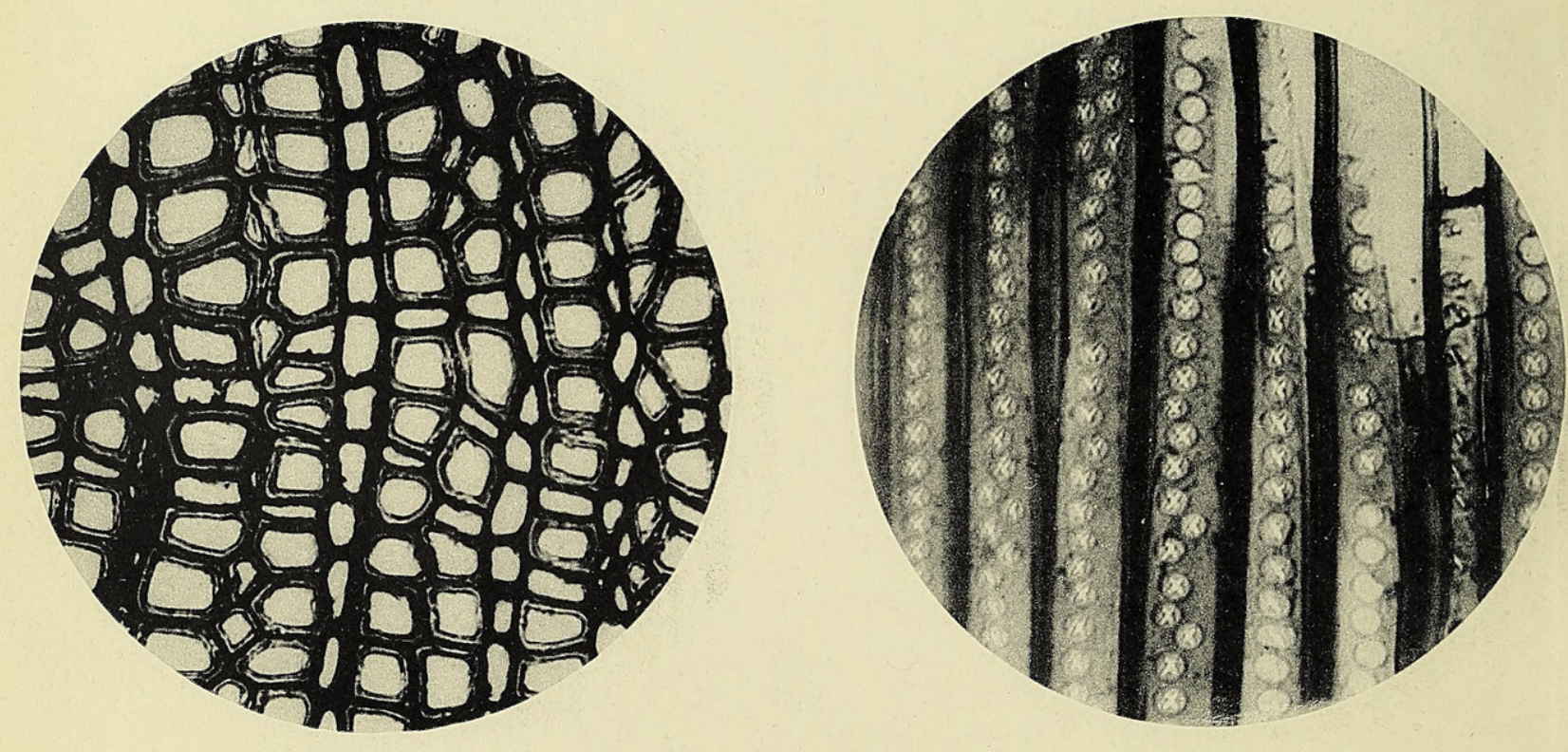

3.

4.
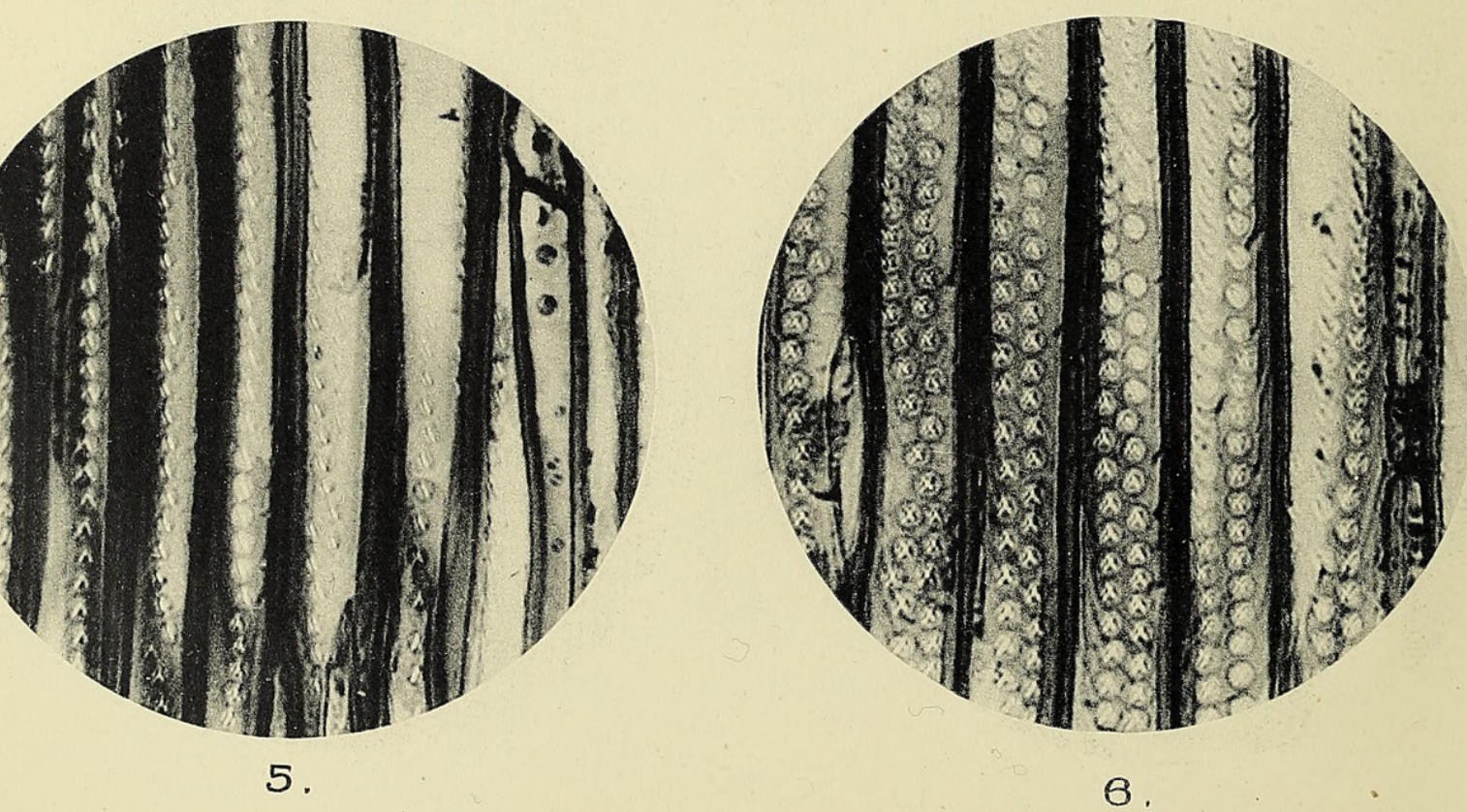

JEFFREY \& COLE -DRIMYS. 
Vol.XXX, PL.VII.

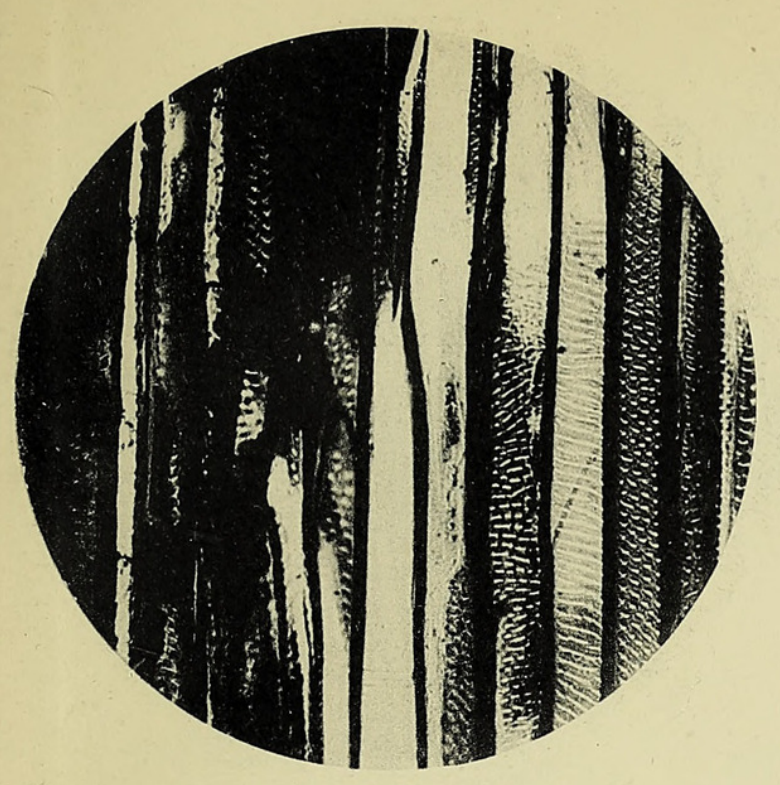

7.
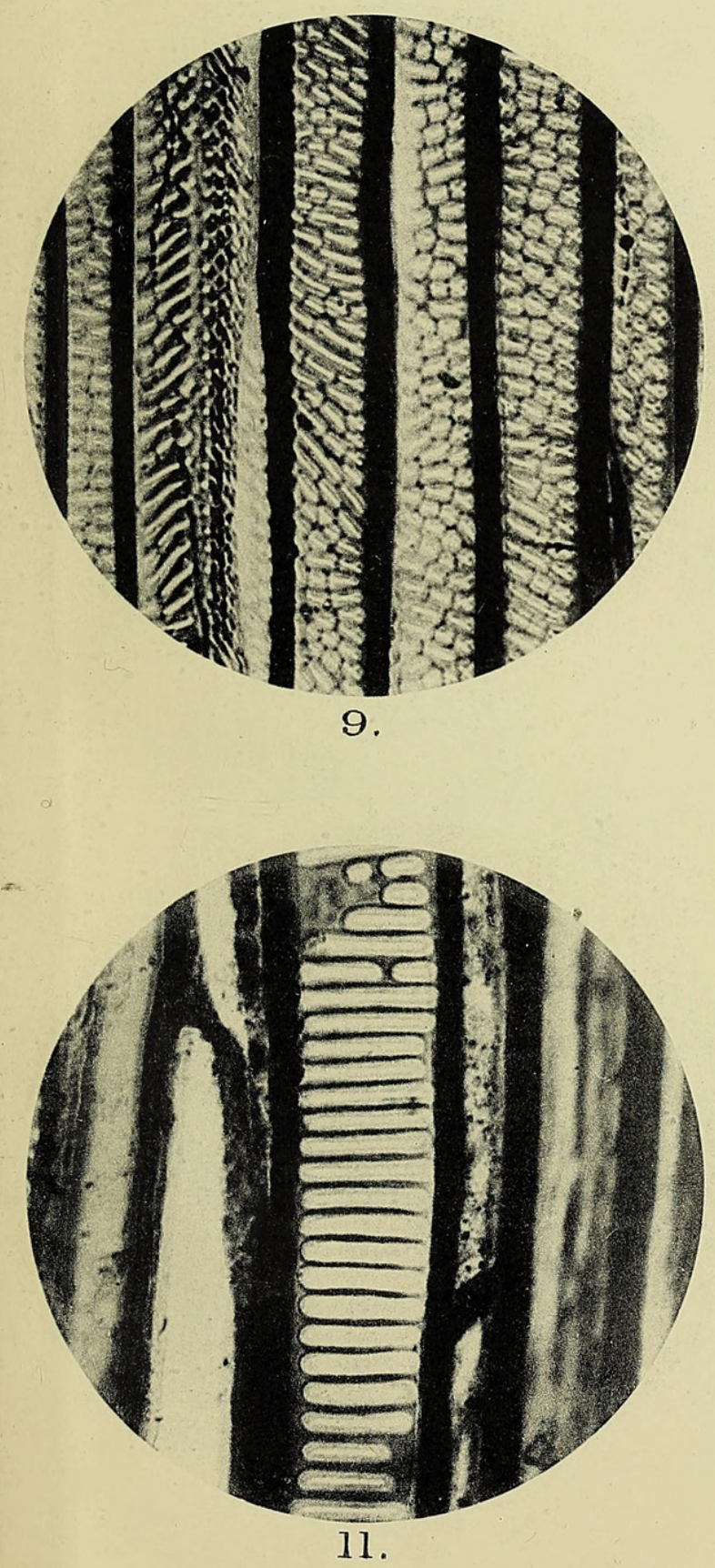
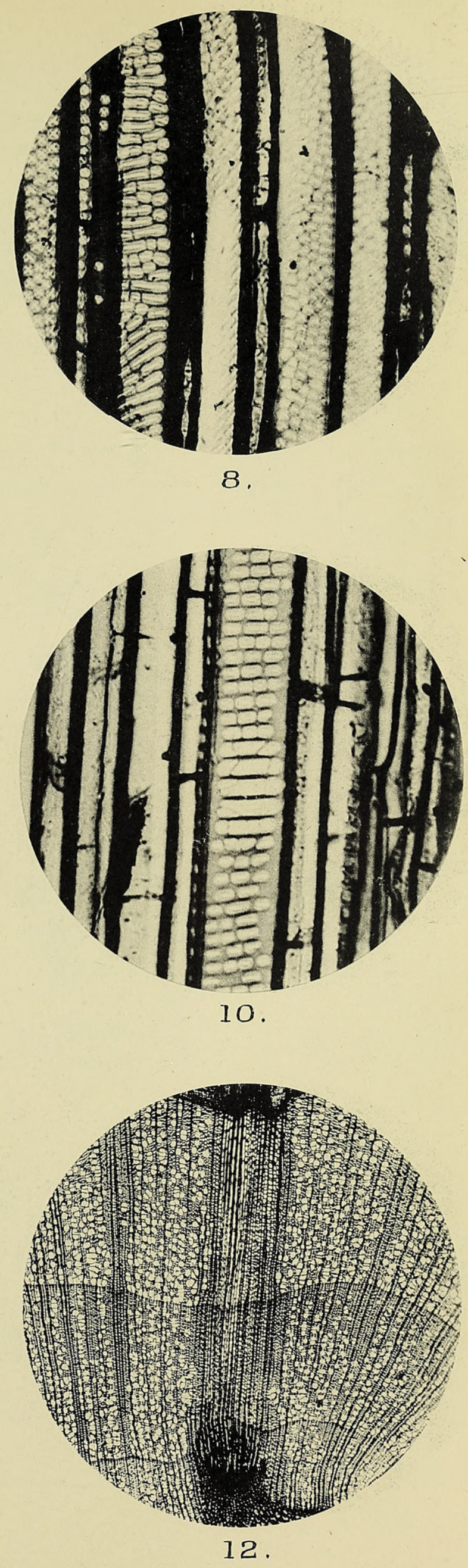

Huth coll 


\section{$2 \mathrm{BHL}$ Biodiversity Heritage Library}

Jeffrey, Edward C. and Cole, Ruth D . 1916. "Experimental investigations on the genus Drimys." Annals of botany 30, 359-368. https://doi.org/10.1093/oxfordjournals.aob.a089603.

View This Item Online: https://www.biodiversitylibrary.org/item/237452

DOI: https://doi.org/10.1093/oxfordjournals.aob.a089603

Permalink: https://www.biodiversitylibrary.org/partpdf/320120

\section{Holding Institution}

Smithsonian Libraries

\section{Sponsored by}

Biodiversity Heritage Library

\section{Copyright \& Reuse}

Copyright Status: Not in copyright. The BHL knows of no copyright restrictions on this item.

This document was created from content at the Biodiversity Heritage Library, the world's largest open access digital library for biodiversity literature and archives. Visit BHL at https://www.biodiversitylibrary.org. 